\title{
Effects of platelets rich fibrin and bone marrow on the healing of distal radial fracture in local dogs: Comparative study
}

\author{
M.G. Thanoon ${ }^{1 *}$, M.J. Eesa ${ }^{2}$ and E.R. Abed ${ }^{3}$ \\ ${ }^{1}$ Department of Surgery and Theriogenology, College of Veterinary Medicine, University of Mosul, Mosul, ${ }^{2}$ Department of \\ Surgery and Obstetrics, College of Veterinary Medicine, University of Baghdad, ${ }^{3}$ Department of Pathology, College of \\ Dentistry, University of Al Iraqia, Baghdad, Iraq, "email: thanoonmoyaser@yahoo.com
}

(Received November 27, 2018; Accepted December 21, 2018)

\begin{abstract}
The aim of this study was to evaluate the effects of platelets rich fibrin and bone marrow on distal radial fracture healing in local breed dogs. Twenty four adult animals (males and females), mean aged $2.6 \pm 0.15$ years, and the mean body weight 24.58 $\pm 1.07 \mathrm{~kg}$ were used. The experimental animals were randomly divided into three equal groups. First group (Control group), transverse fracture was induced in the distal portion of radial bone and immobilized by Plaster of Paris, the fracture line didn't treated with any material. Second group (platelets rich fibrin group), the fracture line was surrounded by the platelets rich fibrin. Third group (bone marrow group), the fracture line was surrounded by autologous bone marrow. The radiographic results confirmed that the fracture healing was faster and superior in third group compared with first and second groups. The hematological results showed an increasing in concentration rates of alkaline phosphatase enzyme and calcium at the weeks that follows surgical operation. Depending on the serial rates of alkaline phosphatase, the third group and the second group are the better fractured bone healing than the first group. In conclusion, the results revealed that, the using of bone marrow and platelets rich fibrin improved and enhanced the healing of distal radial fracture.
\end{abstract}

Keywords: Dog, Fracture, Radial bone, Bone marrow, Platelets rich fibrin Available online at http://www.vetmedmosul.com

$$
\begin{aligned}
& \text { تأثير اللافين الغني بالصفيحات الدموية ونخاع العظم على شفاء كسر الجزء القاصي لعظم الكعبرة في } \\
& \text { الكلاب المحلية: دراسة مقلة مقارنة } \\
& \text { ميسر غانم ذنون'، محمه جواد عيسى ' و أنتصار رحيم عبيد }
\end{aligned}
$$

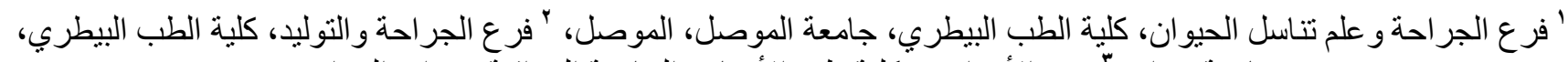

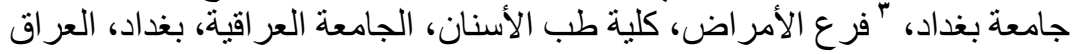

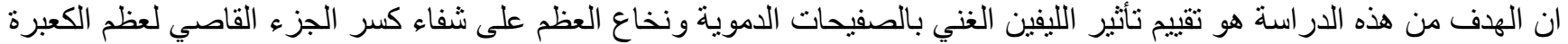

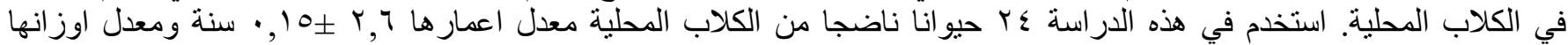

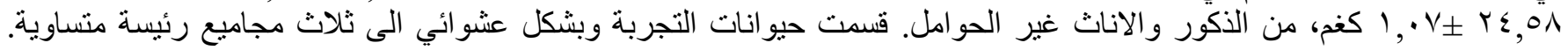

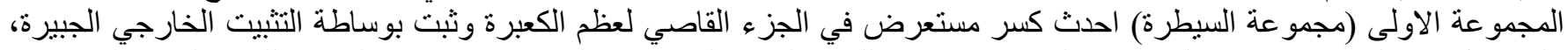

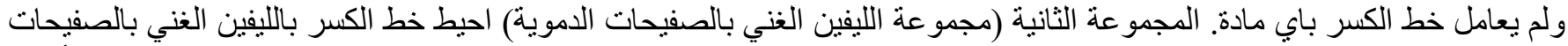

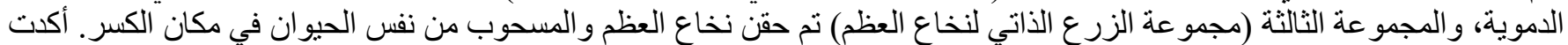

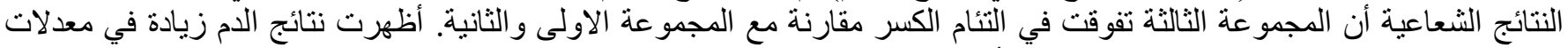

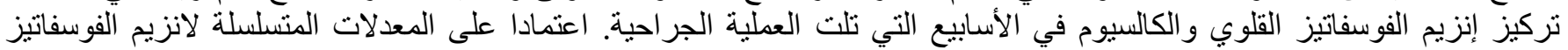




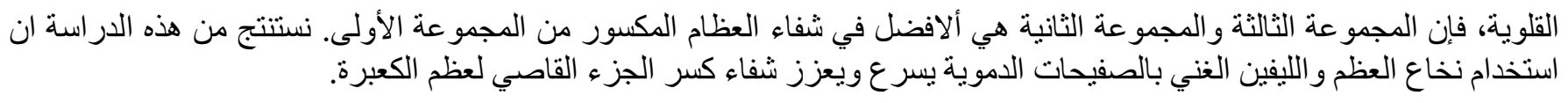

\section{Introduction}

The distal radial fracture is considered third most common fracture in dogs. They represent approximately $17 \%$ of the all canine fractures and about $85 \%$ of the all radial fractures (1). Radius bone carries the heavier weight of the fore limb compared with the ulna in dogs therefore is more susceptible for fractures than ulna (2). The traumatic injuries which result from traffic accidents, fighting, fall, gunshot and explosive projectiles are the main causes of distal radial fractures (3). Reduce blood supply of distal radius region with little of soft tissues enveloping the fractured site, considered as the most important factors contributes for delayed or incomplete healing of distal radial fracture (2). Therefore the delay-union, mal-union or even non-union healing is common in distal radial fracture especially in toy breeds dogs (4).

The platelets rich fibrin (PRF) is a therapeutic concept of the second generation of platelets concentrate in a fibrin membrane (5). The platelets regulate the healing process including cellular migration, proliferation, and angiogenesis, also it is control the cell apoptosis and interaction with progenitor cells (6). Therefore the PRF is considered a bioactive surgical additive having crucial role not only as hemostasis but also regulate inflammatory process with accelerate wound healing and bone regeneration (7). Platelet is highly specialized secretory cell release growth factors with cytokines to improve healing process (8). These platelet growth factors enhance chemotaxis, induction, differentiation and proliferation of progenitor osteoblasts and influences on bone cells activity (9).

Bone marrow (BM) is a soft spongy like tissue filling the cavities of long bones. It is a network of blood vessels and special connective tissue. The main function of bone marrow is manufacture of blood cells including erythrocytes, leukocytes, and platelets (10). The bone marrow mesenchymal stem cells (MSCs) having ability to differentiate in to a various body cells including myocytes, chondrocytes, osteoblasts, adipocytes and endothelial stem cells that form blood vessels (11). The autologous bone marrow transplantation is one of the most advantageous cell sources for promoting both osteogenesis and angiogenesis. Therefore the therapeutic advantages of using of autologous bone marrow in veterinary medicine are easy, rapid, and less expensive procedure, preservation of early progenitor properties and no delay between harvest and treatment (12). The aim of this study was radiological evaluation of effects of platelets rich fibrin and bone marrow on healing of distal radial fracture in local dogs.

\section{Materials and methods}

This study was conducted on 24 adult animals of local breed dogs (males and non-pregnant females), mean aged $2.6 \pm 0.15$ years, and the mean body weight $24.58 \pm 1.07 \mathrm{~kg}$. The animals housed indoor under the same feed and management conditions, in the animals' house of Veterinary Medicine College, University of Baghdad. The experimental animals were randomly divided into three equal groups, the first group (control group); the second group (Platelets Rich Fibrin group); and the third group (bone marrow group).

The surgical operation was conducted under aseptic preparation and condition. Food was withheld for 24 hours and water for 12 hours before operation. Transverse fracture was induced at the distal portion of radial bone in all experimental animals, under general anesthesia by Xylazine hydrochloride 2\% with Ketamine hydrochloride $10 \%$ at a dose $5 \mathrm{mg} / \mathrm{kg}$ and $15 \mathrm{mg} / \mathrm{kg} \mathrm{B.W.,} \mathrm{respectively.}$ The cranio-medial aspect is the best surgical approach for induce distal radial fracture by using a wire saw (13). The fractured bone immobilized by Plaster of Paris. Post operative care including daily wound management and dressing, with intramuscularly injection of penicillinstreptomycin at a dose of $10000 \mathrm{IU}, 20 \mathrm{mg} / \mathrm{kg} \mathrm{B.W.,}$ respectively for 5 consecutive days. The thread stitch was removed at 10-12 days after operation. In the first group (C), the fracture line didn't treat with any substance; while in the second group (PRF) the fracture line was surrounded by the PRF, which prepared just before beginning of operation, by drawing a whole blood 10cc from cephalic vein collected in test tube without anticoagulants then centrifuged at $3000 \mathrm{rpm}$ for 10 minutes, after centrifugation we will obtained a tube having three layers; the top one it is poor platelets plasma, the middle one it is the platelets rich fibrin, and at the bottom of the tube it's a red blood cells (RBC) layer. The middle layer was separated from the bottom one by surgical scissor (Figure 1) (14). In the third group (BM), the fracture line was surrounded by autologous bone marrow not exceed $5 \mathrm{cc}$, which aspirated from proximal end of femoral bone by Jamshidi needle of the same animal (Figure 2) (15).

All experimental animals were clinically observed daily for 2 weeks then weekly until the end of operation (the follow up10 weeks). Radiological examination of the fractured bone began by taking a radiographic picture immediately after completion of surgery to ensure that the two ends of fractured bone were alignment then took the radiographs every two weeks till end of experiment. The total calcium and alkaline phosphatase enzyme 
concentration was measured by colorimetric method by using a "Spinreact" kit from Spanish for calcium, and "Biolabo" kit from French company for alkaline phosphatase enzyme. Blood samples were drawn at the zero time before surgery, then at 2, 4, 6 weeks after operation, from all experimental animals. All statistical analysis were performed by using the statistical analysis program Sigma Stat (Jandel scientific software V3.1), at a level of probability less than $0.05(\mathrm{P}<0.05)$.

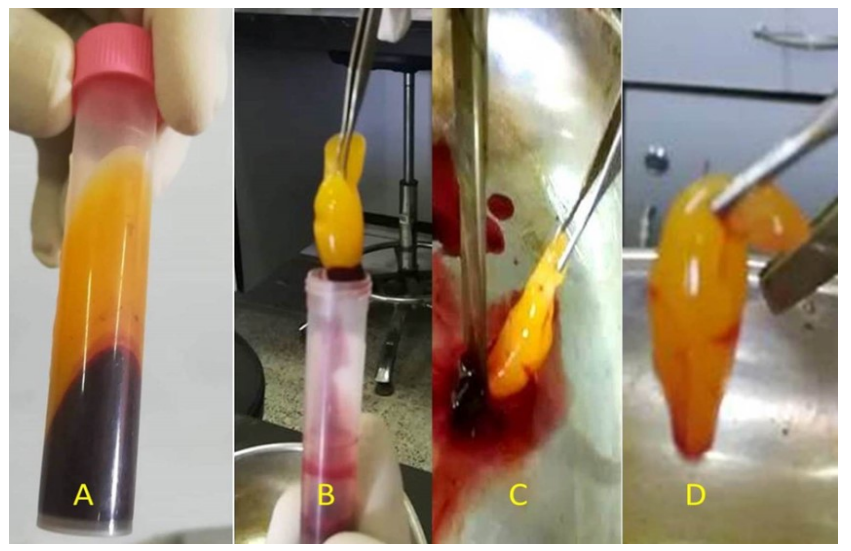

Figure 1: Shown preparations of platelets rich fibrin. A: Test tube after centrifugation having three layers, the top one it is poor platelets plasma, middle PRF, and at the bottom layer it's a red blood cells. B: Extract PRF by surgical forceps from test tube. C: Detach PRF layer from RBC layer by surgical scissors. D: PRF layer alone.

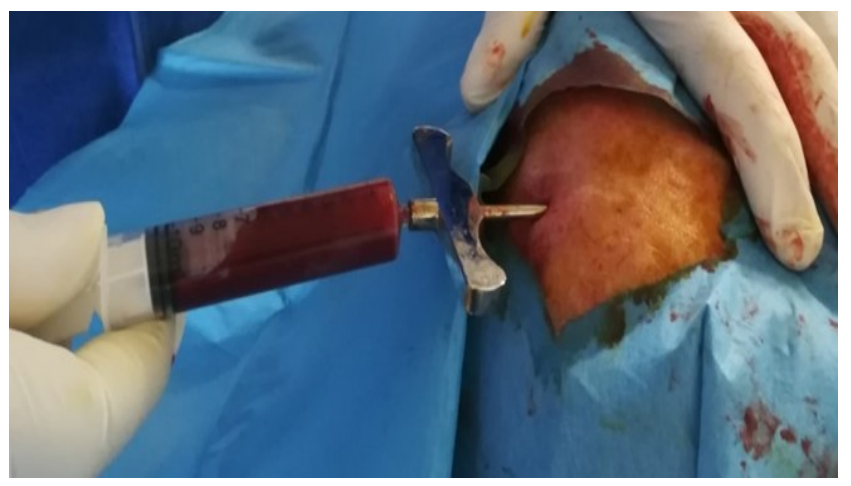

Figure 2: Shown bone marrow aspiration by Jamshidi needle from the proximal end of femoral bone.

\section{Results}

Clinically all animals suffered from partial loss of appetite at first and second days post-operation, the normal appetite returned after 3-4 days of operation. The surgical site showed slight swelling without any inflammatory or serous secretions. The healing of external wound was occurred without any serious complications. Most inflammatory signs of simple swelling and redness at the area of operation disappeared within 3-5 days after operation. Skin stitches were removed from all experimental animals at 10-12 days after operation. The lameness was clear in all experimental animals until the end of the first week post operation, where the animal raised its fractured limb from the first day until the end of the first week post operation. In the third group their ability to use the fractured limb at the end of the second week post operation, while the second group showed their ability to bearing its weight on the fractured limb at the third week after operation. The first group was late in using the fractured limb compared to the first and second groups.

The hematological results showed an increasing in concentration rates of calcium and alkaline phosphatase enzyme at the weeks that follows surgical operation. This results with its statistical analysis summarized in the table 1 for calcium and table 2 for alkaline phosphatase enzyme.

The radiographic images confirmed that fracture healing was faster and superior in the third group compared with the first and second groups. The results of radiographical findings of three groups are summarized in (Table 3).

Table 1: Calcium concentration rates $(\mathrm{mg} / \mathrm{dL})$ with its statistical analysis in the three main groups of experiment

\begin{tabular}{lccc}
\hline Times & $\begin{array}{c}\text { First group } \\
\text { C }\end{array}$ & $\begin{array}{c}\text { Second group } \\
\text { PRF }\end{array}$ & $\begin{array}{c}\text { Third group } \\
\text { BM }\end{array}$ \\
\hline 0 & $9.53 \pm 0.46 \mathrm{a}$ & $9.40 \pm 0.43 \mathrm{a}$ & $9.74 \pm 0.47 \mathrm{a}$ \\
$2 \mathrm{~W}$ & $10.19 \pm 0.55 \mathrm{a}$ & $12.44 \pm 0.45 \mathrm{~b}$ & $12.93 \pm 0.44 \mathrm{~b}$ \\
$4 \mathrm{~W}$ & $10.99 \pm 0.41 \mathrm{a}$ & $12.79 \pm 0.55 \mathrm{a}, \mathrm{b}$ & $13.39 \pm 0.81 \mathrm{~b}$ \\
$6 \mathrm{~W}$ & $12.01 \pm 0.88 \mathrm{a}$ & $10.86 \pm 0.48 \mathrm{a}$ & $11.00 \pm 0.44 \mathrm{a}$ \\
\hline
\end{tabular}

The symbol 0 represents the time before the operation, and $2 \mathrm{~W}, 4 \mathrm{~W}, 6 \mathrm{~W}$ represents the time in weeks after the operation. The different small letters $(a, b)$ indicate that there is a significant difference between the three groups at probability level less than $0.05(\mathrm{P}<0.05)$.

Table 2: Mean of Alkaline Phosphatase concentration rates $(\mathrm{U} / \mathrm{dL})$ with its statistical analysis in the three main groups of experiment

\begin{tabular}{lccc}
\hline Time & $\begin{array}{c}\text { First group } \\
\text { C }\end{array}$ & $\begin{array}{c}\text { Second group } \\
\text { PRF }\end{array}$ & $\begin{array}{c}\text { Third group } \\
\text { BM }\end{array}$ \\
\hline 0 & $20.29 \pm 0.87 \mathrm{a}$ & $21.10 \pm 1.55 \mathrm{a}$ & $18.80 \pm 1.66 \mathrm{a}$ \\
$2 \mathrm{~W}$ & $22.39 \pm 1.70 \mathrm{a}$ & $28.38 \pm 1.60 \mathrm{~b}$ & $35.01 \pm 2.38 \mathrm{c}$ \\
$4 \mathrm{~W}$ & $26.31 \pm 1.99 \mathrm{a}$ & $31.14 \pm 3.71 \mathrm{a}, \mathrm{b}$ & $38.40 \pm 3.27 \mathrm{~b}$ \\
$6 \mathrm{~W}$ & $29.75 \pm 2.73 \mathrm{a}$ & $41.25 \pm 3.60 \mathrm{~b}$ & $43.07 \pm 3.96 \mathrm{~b}$ \\
\hline
\end{tabular}

The symbol 0 represents the time before the operation, and $2 \mathrm{~W}, 4 \mathrm{~W}, 6 \mathrm{~W}$ represents the time in weeks after the operation. The different small letters $(a, b)$ indicate that there is a significant difference between the three groups at probability level less than $0.05(\mathrm{P}<0.05)$. 
Table 3: Shows radiographic finding of first group C, second group PRF, and third group BM

\begin{tabular}{|c|c|c|c|}
\hline Week & Group C & Group PRF & Group BM \\
\hline 2 & $\begin{array}{l}\text { Weak periosteum interaction and } \\
\text { callus formation. Clear fracture } \\
\text { Line (Figure 3-C). }\end{array}$ & $\begin{array}{l}\text { Active periosteum interaction and } \\
\text { callus formation near to the fracture } \\
\text { ends. Clear fracture } \\
\text { Line (Figure 3-PRF). }\end{array}$ & $\begin{array}{l}\text { Active periosteum interaction and } \\
\text { callus formation near to the fracture } \\
\text { ends. Clear fracture line (Figure 3- } \\
\text { BM). }\end{array}$ \\
\hline 4 & $\begin{array}{l}\text { A simple increase in callus size } \\
\text { with partial bridged of the fracture } \\
\text { line. Clear fracture } \\
\text { Line (Figure 4-C). }\end{array}$ & $\begin{array}{l}\text { A good increase in callus size with } \\
\text { partial bridged of the fracture line. } \\
\text { The fracture line is semi-clear } \\
\text { (Figure 4-PRF). }\end{array}$ & $\begin{array}{l}\text { A good increase in callus size with } \\
\text { bridged of the fracture line. The } \\
\text { fracture line is less pronounced } \\
\text { (Figure 4-BM). }\end{array}$ \\
\hline 6 & $\begin{array}{l}\text { An increase in callus size with } \\
\text { partial bridged of the fracture line. } \\
\text { The fracture line is semi-clear } \\
\text { (Figure 5-C). }\end{array}$ & $\begin{array}{l}\text { An increase in callus size with } \\
\text { bridged of the fracture line. The } \\
\text { fracture line is less pronounced } \\
\text { (Figure 5-PRF). }\end{array}$ & $\begin{array}{l}\text { An increasing in callus formation } \\
\text { and its size with bridged more than } \\
\text { half of the fracture line. Fracture line } \\
\text { partially disappeared (Figure 5-BM). }\end{array}$ \\
\hline 8 & $\begin{array}{l}\text { An increasing in callus formation } \\
\text { with partially disappeared of } \\
\text { fracture line (Figure 6-C). }\end{array}$ & $\begin{array}{l}\text { The fractured bone becomes semi- } \\
\text { normal shape, with presence of callus } \\
\text { around the fractured site (Figure 6- } \\
\text { PRF). }\end{array}$ & $\begin{array}{l}\text { The bone shape has become almost } \\
\text { normal, with a decline in callus size } \\
\text { around the fracture site (Figure 6- } \\
\text { BM). }\end{array}$ \\
\hline 10 & $\begin{array}{l}\text { The fractured line disappeared with } \\
\text { the little size of callus around the } \\
\text { fractured site (Figure 7-C). }\end{array}$ & $\begin{array}{l}\text { The fractured bone almost became } \\
\text { normal shaped (Figure 7-PRF). }\end{array}$ & $\begin{array}{l}\text { The fractured bone appears normal } \\
\text { shape (Figure 7-BM). }\end{array}$ \\
\hline
\end{tabular}
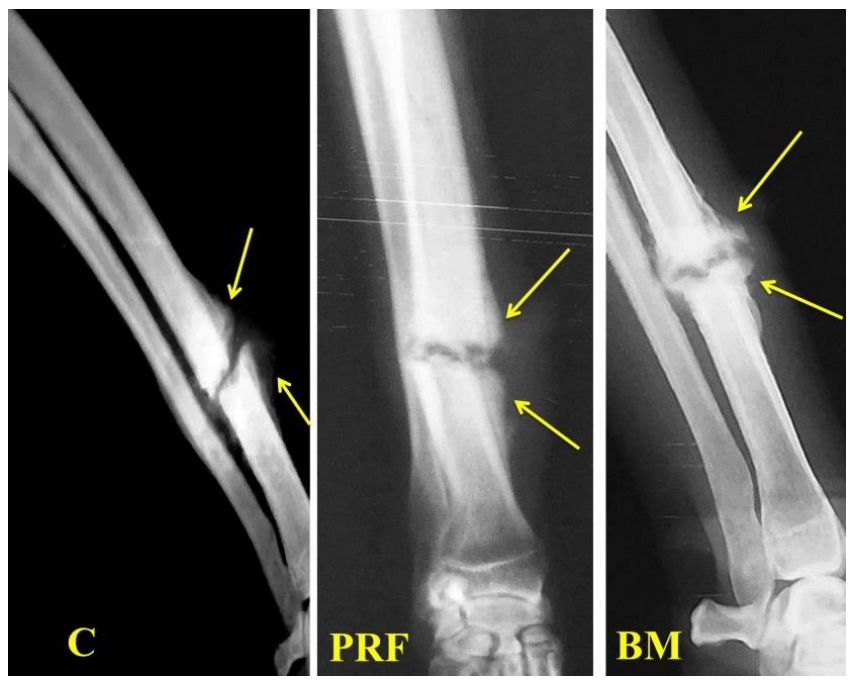

Figure 3: Radiograph of dog's radial bone, at the second week after operation. The active periosteum reaction and callus formation near to the fracture ends (arrows) in both third group (BM) and second group (PRF), while weak periosteum reaction and callus formation (arrows) in first group $(\mathrm{C})$. The fracture line is clear in the first group and slightly visible in both second group and third group.
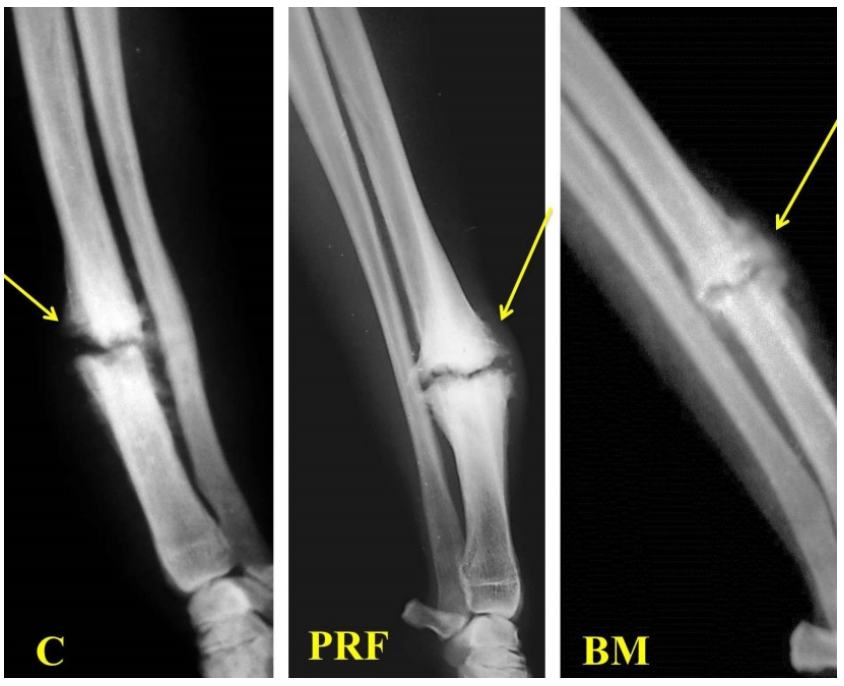

Figure 4: Radiograph at the fourth week after operation. There is an increase in callus formation with bridged fracture line (arrow) in third group (BM). Also there is an increase in callus formation with partially bridged fracture line (arrow) in second group (PRF). Where is simple increase in callus size with partial bridged fracture line (arrow) in first group (C). The fracture line is clear in the first group and is semi-clear in the second group and less pronounced in the third group. 

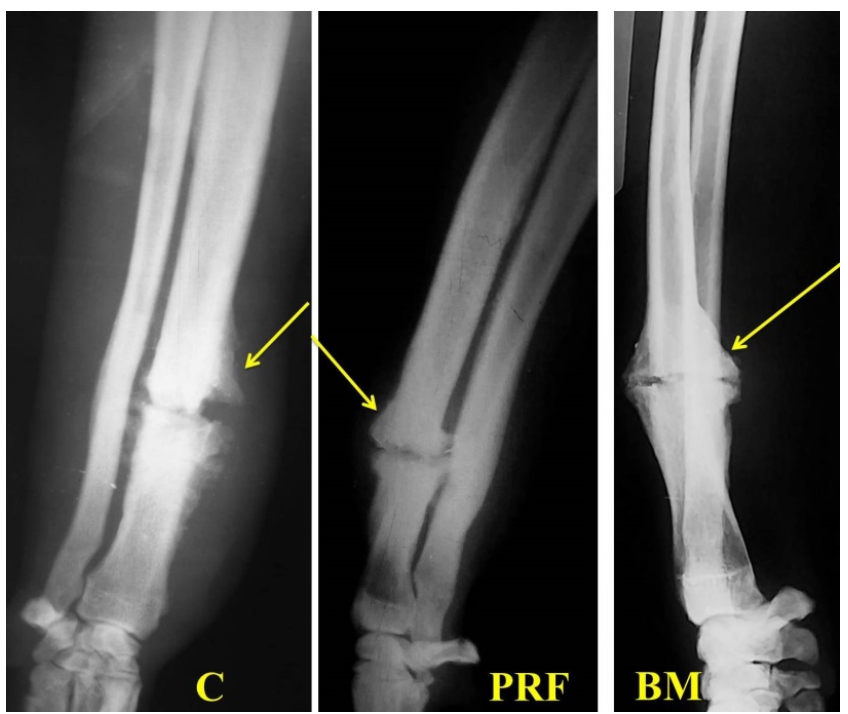

Figure 5: Radiograph at the sixth week after operation. In the third group (BM), an increasing in callus formation and its size with bridged more than half of fracture line (arrow). In the second group (PRF), an increasing in callus formation with bridged of the fracture line (arrow). In the first group (C), an increase in callus size formation with partial bridged of the fracture line. The fracture line partially disappeared in third group, less pronounced in second group, and semi-clear in the first group.
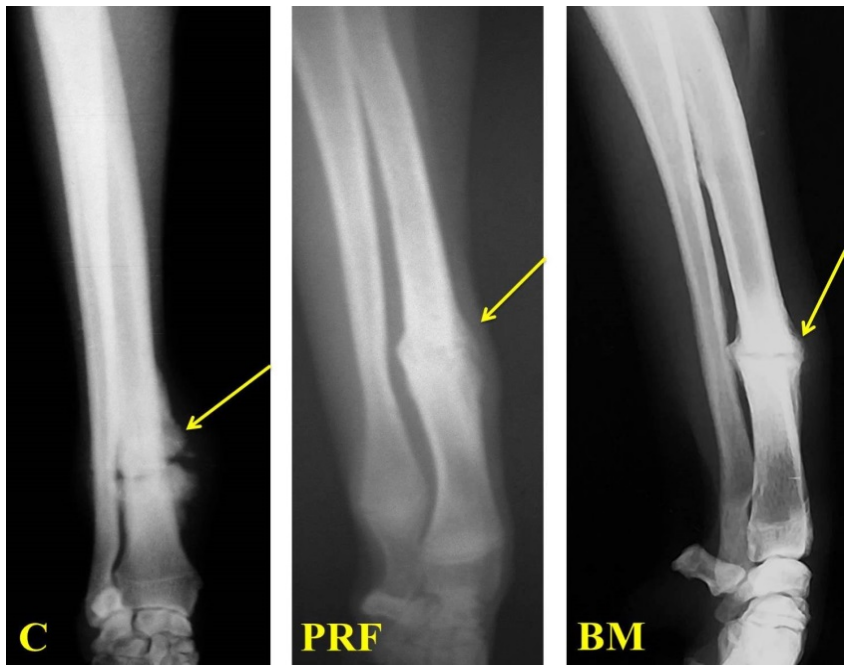

Figure 6: Radiograph at the eight week after operation. In the third group (BM), the bone shape has become almost normal, with a decline in callus size around the fracture site (arrow). In the second group (PRF), the fractured bone becomes semi-normal shape, with presence of callus around the fractured site (arrow). In the first group (C), an increasing in callus formation with partially disappeared of fracture line (arrow).
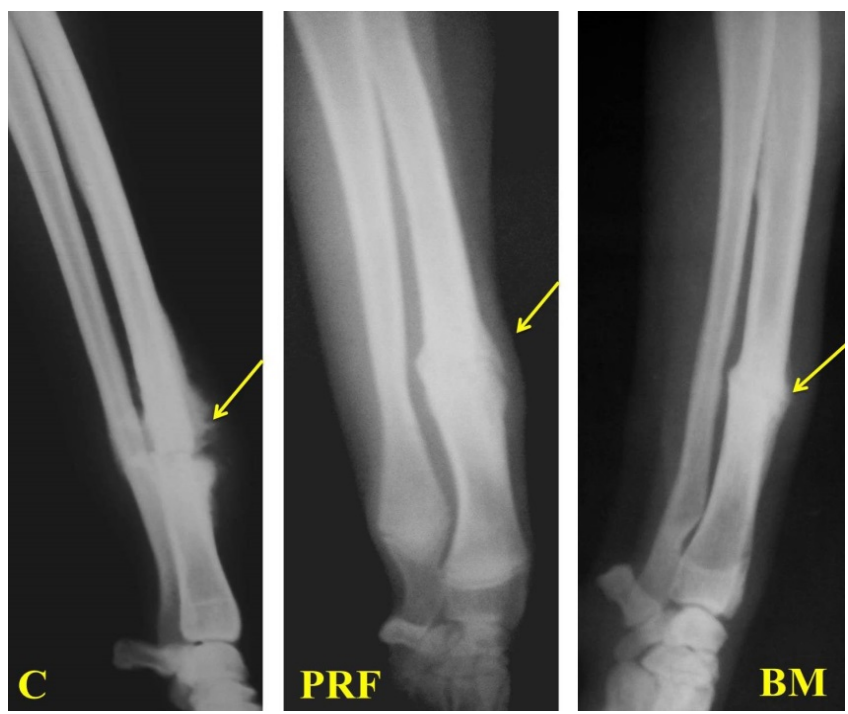

Figure 7: Radiograph of dog's radial bone, at the ten week after operation. In the third group (BM), the fractured bone appears normal shape (arrow). In the second group (PRF), the fractured bone almost became normal shaped (arrow). In the first group (C), the fractured line disappeared with the little size of callus around the fractured site (arrow).

\section{Discussion}

All experimental animals suffered from lameness, and it's a major clinical sign of distal radial fracture. The lameness was evident at the first and second weeks and less visible in the third and fourth weeks then almost disappeared at the sixth week. These results coincides by McCartney et al. and Manchi et al. $(4,16)$, whom said that, the lameness is clinically cleared when the distal radial fracture accompanied by ulnar fracture and is less when only distal radial fracture without ulnar fracture.

The radiographic pictures of second week after operation showed better fracture healing response in the second group represented by active periosteum interaction and callus formation near the fractured ends, than the first group that's showed weak periosteum interaction and callus formation. The reason of good fracture healing response may due to adding of PRF at the fracture line in the second group, and didn't use any bioactive materials in the first group. This agree with Moshiri \& Oryan and Davis et al. $(17,18)$, whom said that, the PRF having an effective regulatory role at the first hours of adding it to the fracture line, by releasing growth factors and cytokines which preserved in the granules of platelets. Also the radiographic pictures of second week after operation showed best fracture healing response in the third group than the first group, this may due to autologous bone marrow plantation at the fracture site. This coincides with Travlos and Korf- 
Klingebiel et al. $(10,19)$, whom said that, the bone marrow contains many types of blood cells, cytokines, growth factors as well as stem cells and all these types cells contributes and enhanced rapid respond for inflammatory processes with a significant early role in bone fracture healing.

The radiographic pictures of sixth week showed that the third group was the best response for healing of fractured bone, represented by an increasing in callus formation and its size with bridged more than half of the fracture line, and the fracture line was partially disappeared. This may due to effect of mesenchymal stem cells in the bone marrow which having ability to multiply and differentiated in to several types of tissues cells including chondroblast, osteoblast and osteocyte, and this is agreements with Crovace et al. and Gomes et al. $(20,2)$, they confirmed that, the mesenchymal stem cells of bone marrow contribute and accelerate the fracture healing. The differences between third group and second group is almost simple in fracture healing response because the concentrated platelets which presents in the PRF contributes and enhance fracture bone healing as well as the fibrin material act as a scaffold between the bone fractured ends with filling the fracture gap, and this is enhance and accelerate distal radial fracture in second group, and this is coincide with Everts et al. and Engebretsen et al. (22,23), whom confirmed that, the platelets plays a crucial role in tissue repairing and regulates the basic mechanisms of inflammation and healing, including proliferation, migration, and differentiation of different inflammatory cells including stem cells.

The radiographic pictures of tenth week showed that the remodeling process was almost complete and the fractured bone appeared normal shape in the third group. This may be due to the recruitment of many cells of osteoblast and osteoclast through the differentiation of stem cells that's found in the region and with those implanted by autologous bone marrow, Therefore the bone marrow has a major role in proliferation and migration of stem cells to divide into osteoblast and osteoclast cells, and this enhance and accelerate fractured bone to heal and reaching remodeling stage which gives the fractured bone normal shape. This is agree with Harwood et al. and Claes et al. $(24,25)$, whom said that, the stage of remodeling of fractured bone begins by removing of all woven bone and fibrocartilagenous matrix tissue by osteoclast cells, which leads to reconstruction of haversian channels and take the bone to its normal shape. The second group was better than the first group in its response for fractured bone healing. This is due to the presence of PRF, and when activation of these platelets will secrete more than 300 bioactive substances from its granules, these growth factors and cytokines responsible for attracting the phagocytes, stem cells and osteoblast. Therefore its responsible for removing of damage and necrotic tissue rather than stimulates and contributes regeneration of tissues and accelerate healing of damaged tissues, and this is agree with Davis et al., Everts et al., Dülgeroglu \& Metineren $(18,22,26)$, whom confirmed that, the platelets its an active biomaterial in the healing of fractures and it increases the amount of formation of bone tissue by reducing the inflammatory period to promote and compensation of fracture healing stage.

The highest concentration rates of alkaline phosphatase enzyme were recorded at the sixth week. So the third group and the second group are the better fractured bone healing than the first group, depending on the serial rates of alkaline phosphatase enzyme concentrations in serum. This is confirmed by Kanwar et al. and Sousa et al. $(27,28)$, they said that, the high levels of alkaline phosphatase in the serum indicated to the activity of osteoblast cells, and new bone formation. There was no significant difference in concentrations rates of calcium in the three main groups despite the increasing in concentrations in the weeks followed the operation. This increase in calcium concentrations refers to the effectiveness and activity of deposition of calcium and the formation of new bone with bone trabeculae and this is coincide with Kumar et al. and Fischer et al. $(29,30)$, whom said that, the calcium is necessary to maintain bone rigidity, and that it is necessary for the deposition of calcium in soft callus and repair of fractured bone. In conclusion, this study revealed that, the using of bone marrow and platelets rich fibrin were hastened and enhanced the healing of distal radial fracture.

\section{References}

1. Brianza SZ, Delise M, Maddalena FM, Amelio PD, Botti P. Crosssectional geometrical properties of distal radius and ulna in large, medium and toy breed dogs. J Biomech. 2006;39(2):302-311. DOI: 10.1016/j.jbiomech.2004.11.018

2. Muir P. Distal antebrachial fractures in toy-breed dogs. Compend Contin Educa Pract Veteri. 1997;19(2):137-145. ISSN 0193-1903

3. Libardoni RN, Serafini GMC, Oliveira C, Schimites PI, Chaves RO, Feranti JPS, Costa CAS, Amara AS, Raiser AG, Soares AV. Appendicular fractures of traumatic etiology in dogs: 955 cases (2004-2013). Ciên Rur San Mar. 2016;46(3):542-546. DOI: $10.1590 / 0103-8478 \mathrm{cr} 20150219$

4. McCartney W, Kiss K, Robertson I. Treatment of distal radial/ulnar fractures in 17 toy breed dogs. Vet Rec J. 2010;166(14):430-432. DOI: $10.1136 /$ vr.b4810

5. Xuzhu W, Yufeng Z, Joseph C, Shahram G, Richard JM. Effects of an injectable platelet-rich fibrin on osteoblast behavior and bone tissue formation in comparison to platelet-rich plasma. Platelets $\mathrm{J}$. 2018;29(1): 1-8. DOI: 10.1080/09537104.2017.1293807

6. Gawaz M, and Vogel S. Platelets in tissue repair: control of apoptosis and interactions with regenerative cells. Bloo J. 2013; 122(15):25502554. DOI: 10.1182/blood-2013-05-468694

7. Dohan DM, Choukroun J, Diss A, Dohan SL, Dohan AJ, Mouhyi J, Gogly B. Platelet-rich fibrin (PRF): A second-generation platelet concentrate. Part I: Technological concepts and evolution. Oral Surg Oral Med Oral Pathol Oral Radiol Endod. 2006;101(3):e37-44. DOI: $10.1016 /$ j.tripleo.2005.07.008 
8. Schär MO, Diaz-Romero J, Kohl S, Zumstein MA Nesic D. Plateletrich concentrates differentially release growth factors and induce cell migration in vitro. Clin Orthop Relat Res. 2015;473(5):1635-43. DOI: 10.1007/s11999-015-4192-2.

9. Joo MW, Chung SJ, Shin HS, Chung YG. The Effect of Autologous Platelet-Rich Plasma on Bone Regeneration by Autologous Mesenchymal Stem Cells Loaded onto Allogeneic Cancellous Bone Granules. Cel Tiss Orga. 2017;203:327-338. DOI: $10.1159 / 000454915$

10. Travlos GS. Normal Structure, Function, and Histology of the Bone Marrow. Toxo Patho. 2006;34(5):548-565. DOI: 10.1080/01926230600939856

11. Birbrair A, and Frenette PS. Niche heterogeneity in the bone marrow. Ann N Y Acad Sci. 2016;1370(1):82-96. DOI: 10.1111/nyas.13016

12. Licheng Z, Lihai Z, Meng X, Qi Y, Peifu T. Autologous Uncultured Bone Marrow-Derived Mononuclear Cells and Modified Cannulated Screw in Repair of Femoral Neck Fracture. J Orthop Res. 2013;31:1302-1307. DOI: 10.1002/jor.22346

13. Raaj V, Gautam A, Abhishek, Kumari P. Platelet-Rich Fibrin (PRF): A New Generation Platelet Concentrate. Int J Dent Med Res. 2015;1(6):164-167. http://www.ijohmr.com/upload/PlateletRich\%20Fibrin\%20(PRF).pdf

14. Laura C, Groza I, Oana L, Pall E, Pestean C, Cătană R, Cenariu M. Canine Mesenchymal Stem Cell Isolation from Bone Marrow Aspirates. Bulle Uni Agri Sci Vet Med. 2008;65(2):96-101. DOI: 10.15835/buasvmen-vm:65:2:1536

15. Pozzi A, and Lewis DD. Surgical approaches for minimally invasive plate osteosynthesis in dogs. Vet Comp Orthop Traum. 2009;22:316320. DOI: 10.3415/VCOT-08-10-0096

16. Manchi G, Brunnberg MM, Shahid M, Al Aiyan A, Chow E, Brunnberg L, Stein S. Radial and ulnar fracture treatment with paraosseous clamp-cerclage stabilization technique in 17 toy breed dogs. Vet Rec Ope. 2017;4(1):1-9. DOI: 10.1136/vetreco-2016000194

17. Moshiri A, and Oryan A. Role of platelet rich plasma in soft and hard connective tissue healing: an evidence based review from basic to clinical application. Hard Tissu. 2013;2(1):6-25. DOI: 10.13172/2050-2303-2-1-326

18. Davis VL, Abukabda AB, Radio NM, Witt-Enderby PA, Clafshenkel WP, Cairone JV, Rutkowski JL. Platelet-rich preparations to improve healing. Part II: platelet activation and enrichment, leukocyte inclusion, and other selection criteria. J Oral Implanto. 2014;40:511521. DOI: 10.1563/AAID-JOI-D-12-00106

19. Korf-Klingebiel M, Kempf T, Sauer T, Brinkmann E, Fischer P, Meyer GP, Ganser A, Drexler H, Wollert KC. Bone marrow cells are a rich source of growth factors and cytokines: implications for cell therapy trials after myocardial infarction. Europ Hear J. 2008;29:2851-2858. DOI: 10.1093/eurheartj/ehn456
20. Crovace A, Favia A, Lacitignola L, Di Comite MS, Staffieri F, Francioso E. Use of autologous bone marrow mononuclear cells and cultured bone marrow stromal cells in dogs with orthopaedic lesions. Vet Res Commun. 2008;32(1):S39-44. DOI: 10.1007/s11259-0089095-1

21. Gomes IS, de Oliveira VC, Pinheiro AO, Roballo KCS, de Araujo GSM, Veronezi JC, Martins DS, Ambrósio CE. Bone marrow stem cell applied in the canine veterinary clinics. Pesq Vet Bras. 2017;37(10):1139-1145. DOI: 10.1590/S0100-736X2017001000016

22. Everts PA, Knape JT, Weibrich G, Schonberger JP, Hoffmann J, Overdevest EP, Box HA, van Zundert A. Platelet-rich plasma and platelet gel: a review. J Ext Corpo Techno. 2006;38(2):174-187. PMID: 16921694

23. Engebretsen L, Steffen K, Alsousou J, Anitua E, Bachl N, Devilee R, Everts P, Hamilton B, Huard J, Jenoure P, Kelberine F, Kon E, Maffulli N, Matheson G, Mei-Dan O, Menetrey J, Philippon M, Randelli P, Schamasch P, Schwellnus M, Vernec A, Verrall G. IOC consensus paper on the use of platelet-rich plasma in sports medicine. $\mathrm{Br}$ J Spor Med. 2010;44:1072-1081. DOI: 10.1136/bjsm.2010.079822

24. Harwood PJ, Newman JB, Michael ALR. An update on fracture healing and non-union. Orthop Trau. 2010;24(1):9-23. DOI: 10.1016/j.mporth.2009.12.004

25. Claes L, Recknagel S, Ignatius A. Fracture healing under healthy and inflammatory conditions. Natur Revi Rheum. 2012;8:133-143. DOI: 10.1038/nrrheum.2012.1 · Source: PubMed

26. Dülgeroglu TC, and Metineren H. Evaluation of the effect of plateletrich fibrin on long bone healing: An experimental rat model. Orthop J. 2017;40(3):e479-e484. DOI: 10.3928/01477447-20170308-02

27. Kanwar G, Yadav M, Kumar S, Kirad S, Jain N. Serum alkaline phosphatase a prospective biomarker for assessment of progress of fracture healing. Intern J Resea Appli Natu Soci. 2014;3(1):15-20. ISSN(E): 2321-8851; ISSN(P): 2347-4580

28. Sousa CP, Dias IR, Lopez-Peña M, Camassa JA, Lourenço PJ, Judas FM, Gomes ME, Reis RL. Bone turnover markers for early detection of fracture healing disturbances: A review of the scientific literature. An Acad Bras Cienc. 2015;87(2):1049-1061. DOI: 10.1590/00013765201520150008

29. Kumar KM, Prasad VD, Lakshmi ND, Raju NKB. Evaluation of biochemical parameters for assessment of fracture healing in dogs. Phar Innov J. 2018;7(3):577-580. ISSN (E): 2277- 7695; ISSN (P): 2349-8242

30. Fischer V, Haffner-Luntzer M, Amling M, Ignatius A. Calcium and Vitamin D in Bone Fracture Healing and Post-Traumatic Bone Turnover. Europ Cel Mater. 2018;35:365-385. DOI: 10.22203/eCM.v035a25 